\title{
METODE EXPERIENTIAL LEARNING DALAM PEMBELAJARAN KETERAMPILAN MENULIS DESKRIPTIF PADA MAHASISWA PENDIDIKAN GURU SEKOLAH DASAR
}

\author{
Patmawati \\ Universitas Terbuka Makassar \\ JL. Monginsidi Baru No 7, Makassar 90142 \\ E-mail: patmawati.wati@email.com
}

\begin{abstract}
This study describes the effectiveness of the application of experiential learning methods in learning descriptive writing skills for PGSD students in Barru's study. The benefits of this study are to inform the effectiveness of experiential learning methods in descriptive writing. This type of research is the one group pretest-posttest design experiment. The research subjects were all PGSD students in the first registration period of 2014.1 totaling 35 people. Data collection techniques are observation and tests. Data analysis techniques are descriptive statistical analysis and $t$-test. The results showed that the results of the comparison of the average student value coefficient (t count) between the experimental class (X1) and the control class (X2) were obtained at $5 \geq t$ tabe 1 at a significant level of $95 \%$, namely $\alpha 0.95=1.70$. Therefore, the $t$ count is greater than $t$ table at a significant level of 95\%, then the null hypothesis (Ho) is rejected and the alternative hypothesis (H1) is accepted. So, $t$-test statistics show that experiential learning methods are effectively used in learning descriptive writing skills in PGSD students teach Barra.
\end{abstract}

Keywords: Experiental, learning, Writing.

\begin{abstract}
Abstrak
Penelitian ini mendeskripsikan keefektivan penerapan metode experiential learning dalam pembelajaran keterampilan menulis deskriptif pada mahasiswa PGSD pokjar Barru. Manfaat penelitian ini untuk menginformasikan keefektivan metode experiential learning dalam menulis deskriptif. Jenis penelitian ini adalah ekperimen one group prestest posttest design. Subyek penelitian semua mahasiswa PGSD masa registerasi pertama 2014.1 yang berjumlah 35 orang. Teknik pengumpulkan data adalah observasi dan tes. Teknik analisis data yaitu analisis statistik deskriptif dan uji t. Hasil penelitian menunjukkan bahwa hasil perbandingan koefisien nilai ratarata siswa ( $t$ hitung) antara kelas eksperimen (X1) dan kelas kontrol (X2) diperoleh sebesar $5 \geq$ t tabe1 pada taraf signifikan 95\%, yaitu $\alpha 0,95=1,70$. Oleh karena, itu thitung lebih besar dari $t$ tabel pada taraf signifikan 95\%, maka hipotesis nol (Ho) ditolak dan hipotesis alternatif (H1) diterima.Jadi, statistik uji $t$ memperlihatkan bahwa metode experiential learning efektif digunakan dalam pembelajaran keterampilan menulis deskriptif pada mahasiswa PGSD pokjar Barra.
\end{abstract}

Kata Kunci,: Experiental, learning, Menulis.

\section{PENDAHULUAN}

Universitas terbuka adalah salah satu universitas yang tersebar di seluruh Indonesia dengan sistem perkuliahan yang bersifat terbuka. Perkulihan di UT tidak dibatasi oleh ruang kelas serta pengajar (dosen) 


\section{2 | Patmawati}

tertentu sehingga daya tampungnya besar dan dengan jangkauan yang cukup besar. Untuk itu, tutor sebagai pengajar diharapkan berkompetensi dalam menciptakan suasana pembelajaran yang mampu meningkatkan kreatifitas mahasiswa dalam bernalar baik secara lisan maupun secara tertulis.

Tutorial merupakan bantuan akademis dari tutor kepada mahasiswa yang diharapkan dapat memacu proses belajar mandiri. Tutorial harus memungkinkan para mahasiswa terdorong untuk mempelajari modul pada taraf menguasai secara mandiri. Tutor harus membantu mahasiswa dalam memecahkan masalah yang dijumpai dalam modul. Proses tutorial yang dilaksanakan pada program S-1 PGSD saat ini menggunakan tutorial tatap muka dan non tatap muka. Tutorial tatap muka merupakan bimbingan belajar yang disampaikan melalui modus tatap muka untuk membantu mahasiswa menguasai materi kuliah serta dapat memberikan kontribusi terhadap peningkatan kemampuan dan kualifikasinya sebagai guru SD dan dapat memperluas visi serta memupuk kemandirian dalam belajar. Untuk itu, tutor berperan sebagai pembimbing proses belajar, narasumber, fasilitator, pengelola dan evaluator kegiatan belajar (Rustan, 2017). Dengan demikian, kemampuan tutor dalam mengelola kegiatan tutorial merupakan salah satu faktor penting yang dapat memotivasi mahasiswa untuk meningkatkan kemampuannya dalam belajar mandiri sehingga materi yang disajikan dapat dikuasai dengan baik. Khususnya pada keterampilan menulis.

Melalui menulis, mahasiswaakan memperoleh pengetahuan dan keterampilan yang bermanfaat bagi pertumbuhan dan perkembangan daya nalar, sosial, serta kebudayaan. Melalui keterampilan menulis pun seseorang dapat merekam, melaporkan, memberitahukan, menyakinkan dan mempengaruhi orang lain. Dengan keterampilan menulis yang memadai, seseorang tidak akan mengalami kesulitan dalam mengekspresikan diri dengan perkembangan dunia modern.

Pada kenyataan keterampilan menulis di kalangan mahasiswa masih kurang memadai. Pembelajaran keterampilan menulis sebagai bagian dalam pembelajaran bahasa Indonesia yang diterimakurang menekankan pada praktik berbahasa bentuk tulisan.Sehingga dalam penuangan ide kedalam bahasa tulis dianggap sulit bagi mahasiswa. Mereka lebih banyak menguasai pengetahuan bahasa daripada keterampilan menulis. Tutor perlu memotivasi mahasiswa, mengembangkan keyakinan akan kemampuan yang dimiliki sehingga terstimulasi untuk mampu meningkatkan keterampilan menulis (Thaha \& Rustan, 2017). Keterampilan berbahasa yang diperoleh lebih terfokus pada penyajian materi daripada praktik.Hal tersebut dampak pada mahasiswa program S-1 PGSD Universitas Terbuka yang cenderung belajar menggunakan modul. Keterampilan berbahasa yang dipelajarinya kurang terserap dengan baik dalam pemahaman mereka, disebabkan oleh penyajian materi kuliah yang cenderung membosankan. Sementara itu, untuk mempersiapkan tenaga pengajar yang kreatif dan berkualitas dituntut memiliki keterampilan berbahasa yang baik, yang bukan hanya pada pemahaman konsep, tetapi juga dalam praktik.

Materi keterampilan menulisinilah yang menjadi hambatan mahasiswa dalam pembelajaran keterampilan berbahasa. Keterampilan menulis sebagai 
suatu keterampilan berbahasa produktif merupakan suatu hal yang paling kompleks yang membutuhkan beberapa syarat penguasaan kosakata, ketatabahasaan, kemampuan menyusun dan merangkaikan gagasan, serta mengembangkan gagasan dalam suatu tulisan yang logis, padat, dan mudah dipahami. Selain itu, dalam menulis harus memperhatikan struktur kalimat dan tata penulisan seperti penggunaan tanda baca, ambiguitas dan diksi karena dapat menyebabkan kerancuan kalimat. Adanya kerancuan kalimat menimbulkan kesulitan dalam membaca yang berakibat pada perbedaan penalaran setiap pembaca (Rustan, 2016). Oleh karena itu, mahasiswa sangat dituntut dapat menguasai aspek-aspek yang termuat dalam keterampilan menulis agar dapat menuangkan gagasannya secara terpadu dan dalam bahasa yang dapat dimengerti oleh pembacanya.

Kegiatan menulis merupakan kegiatan yang menggunakan proses berpikir. Proses berpikir tersebut dilakukan penulis dalam dua hal, yakni apa dan bagaimana cara menulis. Apa yang ditulis berkaitan dengan gagasan atau materi yang akan ditulis, sedangkan bagaimana cara menulis berkaitan dengan pengembangan gagasan. Proses menggali materi yang akan ditulis dilakukan melalui kegiatan pemilihan tema dan topik, pengumpulan bahan, perencanaan penataan tulisan, penetapan tujuan menulis dan pengembangan gagasan. Sejalan dengan pernyataan tersebut, Enre (1994) mengatakan bahwa salah satu tugas penting seorang penulis ialah menguasai cara menulis dan berpikir akan banyak membantu dalam usaha pencapaian sesuatu tujuan yang penting. Untuk itu,salah satu yang menarik perhatian peneliti adalah perihal menulis deskriptif. Wacana deskripsi adalah bentuk wacana yang berusaha menyajikan sesuatu objek, sehingga objek itu seolah-olah berada di depan pembaca, seakan-akan para pembaca melihat sendiri objek itu (Alwi dkk, 2002:97). Dapat dikatakan bahwa wacana deskripsi seakan-akan pembaca seolah-olah dapat melihat dan merasakan hal yang yang dilukiskan.Pembaca diajak mengalami yang dibacanya.

Ahli lain berpendapat bahwa tentang deskripsi adalah semacam bentuk wacana yang berusaha menyajikan suatu objek sedemikian rupa sehingga objek itu seolah-olah berada di depan pembaca. Seakan-akan para pembaca melihat sendiri objek itu. Alwi (Rahman, 2005: 26). Nursito (Rahman, 2005: 25) menyatakan bahwa deskripsi (pemerian) berarti wacana yang melukiskan sesuatu sesuai dengan keadaan yang sebenarnya sehingga pembaca dapat mencintai (melihat, mendengar, merasakan, dan mencoba).

Berdasarkan pendapat tersebut, penulis dapat menyimpulkan bahwa paragraf deskripsi adalah karangan yang melukiskan sesuatu sesuai dengan objeknya agar pembaca seakan-akan melihat, merasakan, dan mendengar apa yang telah dilukiskan oleh penulis.

Metode experientiallearning adalah suatu proses belajar mengajar yang mengaktifkan pembelajar untuk membangun pengetahuan dan keterampilan serta nilai-nilai juga sikap melalui pengalamannya secara langsung. Oleh karena itu, metode ini akan bermakna tatkala pembelajar berperan dalam melakukan kegiatan. Setelah itu, mereka memandang kritis kegiatan tersebut.Kemudian, mereka mendapatkan pemahaman serta menuangkannya dalam bentuk lisan atau tulisan sesuai dengan tujuan 


\section{4 | Patmawati}

pembelajaran. Dalam hal ini, experentiallearning menggunakan pengalaman sebagai katalisator untuk menolong pembelajaran mengembangkan kapasitas dan kemampuannya dalam proses pembelajaran.

Subana (2008:165) mengemuakakan prinsip-prinsip metode pembelajaran experientiallearning yaitu:

1) Belajar berdasarkan pengalaman itu merupakan suatu proses perbuatan generalisasi dan kesimpulan tentang pengalaman langsung.

2) Belajar melalui pengalaman menekankan pengalaman langsung mengenai hal yang sedang dipelajari, menentukan keterikatan untuk belajar dan bertanggung jawab terhadap pengorganisasian kesimpulan yang ditarik dari pengalaman sendiri.

3) Teori yang tepat dapat membantu mahasiswa untuk menyimpulkan sendiri pelajarannya dan membentuk kerangka pengetahuannya.

4) Dalam belajar melalui pengalaman, perasaan sangat penting sebagai sumber informasi tentang diri sendiri dan situasi belajar.

Hal yang perlu diperhatikan dalam menuntun experiential learning ialah walaupun experiential learning itu menarik, mendorong dan melibatkan kegiatan belajar, perlu diingat bahwa pengalaman itu sendiri tidaklah menguntungkan kalau tidak ditopang pemahaman (konsep tualisasi) dari pengalaman itu.sarana belajar yang dapat menciptakan ilmu pengetahuan.

Dalam hal ini penulis tertarik menerapkan metode experiential learning sebuah metode pembelajaran yang berdasarkan pengalaman. untuk melaksanakan dan mengelola tutorial secara efektif dan efisien. Penerapan metode experiential learning dalam tutorial pun merupakan usaha untuk mengefektifkan dan mengefisienkan pembelajaran khususnya pada keterampilan menulis.

Penelitian yang dilakukan tim pengembang Universitas Terbuka memberikan beberapa hasil yang cukup maksimal mengenai pembelajaran model tutorial di UT dan selanjutnya, hasil penelitian tersebut dikembangkan menjadi sebuah pedoman atau acuan yang diharapkan dapat diterapkan bagi pembelajaran di UT. Model tutorial yang dimaksud mengacu pada pengembangan model tutorial tertulis yang dikembangkan ke dalam lima model tutorial tertulis lainnya (Tim pengembang UT, 2007).Adapun manfaat Secara teoritis, hasil penelitian ini diharapkan dapat memberikan informasi yang lebih rinci dan mendalam tentang keefektifan penggunaan metode experiential learning dalam pembelajaran menulis

Secara praktis, hasil penelitian ini diharapkan dapat mendorong inisiatif pada dosen atau tutor untuk mengembangkan jenis keterampilan menulis khususnya dalam pembelajaran menulis desktiptif, serta dapat dijadikan sebagai salah satu alternatif untuk memecahkan masalah kemampuan menulis deskriptif bagi mahasiswa khususnya mahasiswa PGSD pokjar Barru dan dapat meningkatkan daya kreativitas mahasiswa menulis deskriptif dengan penerapan metode experientiallearning.

Alasan lain mengapa penulis tertarik meneliti pada wacana/tulisan deskriptif adalah (1) data dan informasi mengenai keefektifan penggunaan metode experiential learning dalam pembelajaran menulis deskriptif belum ditemukan(2) metode experiential learning sangat tepat di gunakan dalam 
menulis deskriptif berdasarkan pengalaman pribadinya ataupun pengalaman orang lain.Untuk itu, rumusan masalah pada penelitian ini adalah bagaimanakahkeefektifan penerapan metode experiential learning dalam pembelajaran menulis deskriptif pada mahasiswaPGSD Pokjar Barru Kab. Barru?. Dengan tujuan mendeskripsikan keefektifan penerapan metode experiential learning dalam pembelajaran menulis deskriptif pada mahasiswa PGSD Pokjar Barru kabupaten Barru.

\section{METODE}

Metode dalam penelitian ini adalah deskriptif kuantitatif. Desain yang digunakan dalam penelitian ini adalah desain penelitian yang bersifat eksperimen jenis eksperimen one group prestest posttest design. Alasan Peneliti memilih desain penelitian ini karena kelas sampel yang digunakan adalah satu kelompok saja tanpa kelompok pembanding atau kelas kontrol mengingat jumlah mahasiswa hanya satu kelompok, namun dalam penelitian ini menggunakan tes awal sebagai pembanding besarnya efek dari eksperimen yang dilakukan. Subyek penelitian ini adalah mahasiswa masa registerasi pertama 2014.1 yang berjumlah 35 mahasiswa yang pada pokjar di Kabupaten Barru. Penarikan sampel dilakukan dengan mengambil semua mahasiswa yang dijadikan sampel adalah mahasiswa masa registrasi pertama 2014.1. Teknik yang digunakan untuk mengumpulkan data dalam penelitian ini adalah observasi dan tes.

Teknik analisis data yang digunakan dalam penelitian ini, yaitu analisis statistik deskriptif dan uji t. Analisis statistik deskriptif untuk mengetahui pengaruh penerapan model tutorial experientiallearning dalam menulis deskriptif, yaitu keaktifan mahasiswa. Analisis uji $t$ digunakan untuk mengetahui ada tidaknya perbedaan hasil pretes atau sebelum pembelajaran menulis deskriptif mahasiswa program S-1 PGSD pokjar melalui model tutorialexperientiallearning dengan mahasiswa yang telah diajar melalui model pembelajaran. Data yang diperoleh melalui tes dikumpulkan dan dianalisis berdasarkan prosedur kerja untuk mengetahui keefektifan metode tutorial experientiallearning dalam pembelajaran menulis deskriptif.

\section{HASIL DAN PEMBAHASAN}

\section{Analisis Data Statistik Deskriptif}

\section{a. Analisis Data Hasil Eksperimen atau Posttest (X1)}

Data dari hasil analisis posttes hasil eksperimen dengan 35 mahasiswa yang dianalisis diperoleh gambaran, yaitu: skor tertinggi yang diperoleh mahasiswa yaitu 95 berjumlah 2 orang (5,71\%), 2 orang mendapat skor 92 $(5,71 \%), 1$ orang mendapat skor $90(2,86 \%), 1$ orang mendapat skor 88 (2,86\%), 7 orang mendapat skor 8 (20\%), 7 orang mendapat skor 80 (20\%), 4 


\section{6 | Patmawati}

orang mendapat skor $78(11,42 \%), 3$ orang mendapat skor $75(8,57 \%), 5$ orang mendapat skor $70(14,29 \%), 2$ orang yang mendapat skor $65(5,71 \%)$, dan 1 orang mendapat skor 58 (2,86\%).

Berdasarkan data tersebut diperoleh mean ideal adalah 60 dan standar deviasi adalah 15 dengan nilai rata-rata pencapaian mahasiswa kelas eksperimen (X.1) posttesadalah 7,5 Hasil nilai rata-rata pencapaian mahasiswa tersebut dikonversikan ke dalam tabel klasifikasi keefetifan penggunaan metode experiential learning dalam pembelajaran keterampilan menulis deskriptif mahasiswa dapat dilihat dalam tabel 1 berikut ini.

\section{Tabel 1. Klasifikasi Tingkat Keterampilan Menulis Deskriptif Mahasiswa pada Hasil Posttes atau Eksperimen (X.1)}

\begin{tabular}{cccc}
\hline No & Interval Nilai & $\begin{array}{c}\text { Tingkat Hasil } \\
\text { Belajar }\end{array}$ & Frekuensi \\
\hline 1. & $9,0-10$ & Sangat tinggi & 6 \\
2. & $8,0-8,9$ & Tinggi & 14 \\
3. & $6,5-7,9$ & Sedang & 7 \\
4. & $5,5-6,4$ & Rendah & 8 \\
5. & $0,0-5,4$ & Sangat rendah & 0 \\
\hline
\end{tabular}

Setelah diperoleh nilai rata-rata keterampilan menulis deskriptif kelas eksperimen melalui hasil posttes (X.1), maka dapat dikatakan bahwa keterampilan menulis deskriptif dengan menggunakan metode experiential learning dikategorikan sedang. Hal ini terlihat pada tabel yang menunjukkan bahwa 7,5 berada pada rentang nilai 6,5 - 7,9 (kategori sedang).

\section{b. Analisis Data Nilai Kelas Pretes (X.2)}

Data dari hasil analisis tes hasil pretes dengan jumlah sampel 35 orang mahasiswa yang dianalisis diperoleh gambaran, yaitu: belum ada mahasiswa yang mampu memperoleh skor 100 sebagai skor maksimal. Skor tertinggi yaitu 8 dengan jumlah mahasiswa 5 orang $(14,29), 7$ orang mahasiswa mendapat nilai 7 (20\%), 11 orang mahasiswa mendapat nilai $6(31,43 \%), 9$ orang mendapat nilai 5 (25,71\%), 3 orang mendapat nilai $4(8,57 \%)$.

Berdasarkan skor mentah tersebut ditentukan mean rata-rata ideal adalah 60 dan standar deviasi sebagai ukuran penyebaran data adalah 15 . Selanjutnya, mean dan standar deviasi yang telah diperoleh ditransfer ke dalam konversi angka berskala 1 - 10. Dan dari data di atas diperoleh gambaran bahwa nilai yang diperoleh mahasiswa pada pretest bervariasi. Belum adamahasiswa yang memperoleh nilai 10. Selanjutnya, jumlah nilai perolehan seluruh mahasiswa pretest dapat dilihat pada tabel 2 berikut ini. 
Tabel 2 Jumlah Nilai Seluruh Mahasiswa pada Pretest $\left(\sum \mathbf{X}_{2}\right)$

\begin{tabular}{cccc}
\hline No & Nilai Y & Frekuensi N & Jumlah Nilai $\sum \mathbf{X}_{\mathbf{2}}$ \\
\hline 1. & 8 & 5 & 40 \\
2. & 7 & 7 & 49 \\
3. & 6 & 9 & 54 \\
4. & 5 & 11 & 55 \\
5. & 4 & 3 & 12 \\
\hline & Jumlah & 35 & 210 \\
\hline
\end{tabular}

Dari tabel 2 diketahui bahwa nilai rata-rata mahasiswa pada pretest adalah 6 Hasil nilai rata-rata siswa tersebut, dapat dikonversikan ke dalam tabel klasifikasi keterampilan dalam menulis deskriptif tanpa penggunaan metode experiential learning dalam dapat dilihat dalam tabel 3 berikut ini.

Tabel 3 Klasifikasi Tingkat Keterampilan Mahasiswa Menulis Deskriptif Pretest (X2)

\begin{tabular}{cccc}
\hline No & Interval nilai & Tingkat hasil belajar & Frekuensi \\
\hline 1. & $9,0-10$ & Sangat tinggi & \\
2. & $8,0-8,9$ & Tinggi & 5 \\
3. & $6,5-7,9$ & Sedang & 7 \\
4. & $5,5-6,4$ & Rendah & 9 \\
5. & $0,0-5,4$ & Sangat rendah & 14 \\
\hline
\end{tabular}

Setelah diperoleh nilai rata-rata keterampilan menulis deskriptif pada pretest (X2), maka dapat dikatakan bahwa keterampilan menulis deskriptif mahasiswa tanpa menggunakan metode Experiential Learning dikategorikan rendah. Hal ini terlihat pada tabel yang menunjukkan bahwa 6 , berada pada rentang nilai 5,5 - 6,4 (kategori rendah).

2. Analisis Eksperimen Keefektifan Penggunaan Metode Experiential Learning dalam Pembelajaran Keterampilan Menulis Deskriptif Mahasiswa.

Dari hasil analisis data tes kelas eksperimen pada hasil posttes (X1) dan pada hasil pretest (X2) dapat diketahui keefektifan penggunaan metode experiential learning dalam pembelajaran keterampilan menulis deskriptifmahasiswa. Untuk menghitung besarnya pengaruh tersebut, digunakan analisis eksperimen dengan rumus uji t pada d.b (NU) $=\mathrm{N}-1=$ $35-1=34$. Diketahui nilai $\sum X_{1}^{2}=49$ dan $\sum X_{2}^{2}=50$ Setelah jumlah $\sum X_{1}^{2}$ dan jumlah $\sum X_{2}^{2}$ didapat t hitung adalah5 dengan menggunakan rumus

$$
t=\frac{M_{1}-M_{2}}{\sqrt{\frac{\sum X_{1}^{2}+\sum X_{2}^{2}}{N(N-1)}}}
$$




\section{8 | Patmawati}

Dari hasil analisis data yang diuraikan, terlihat bahwa nilai eksperimen atau hasil prostes ( $\mathrm{t}_{\text {hitung}}$ ) yang diperoleh sebesar $=5$ dengan d.b 35-1 $=34$ pada taraf signifikasi 5\% dan kepercayaan 95\% doperoleh t.s $0,95=1.70$ (dapat dilihat pada tabel)

Jadi $t_{\text {hitung }}=5$ dan $t_{\text {tabel }}=1$,70dengan demikian, $t_{\text {hitung }}>t_{\text {tabel }}$

Hipotes yang akan diuji dengan statistik uji t adalah keefektifan metode experiential learning dalam pembelajaran keterampulan menulis deskriptif pada mahasiswa PGSD. Dalam penelitian ini terungkap bahwa mahasiswa yang menggunakan metode experiential learning dalam pembelajaran keterampilan menulis deskriptif mempunyai keterampilan menulis deskriptif secara efektif lebih tinggi daripada tidak menggunakan metode experiential learning dalam menulis deskriptif. Maka pengetesan yang digunakan adalah pengetesan satu arah.

Dalam pengujian statistic, hipotesis ini dinyatakan sebagai berikut:

HO: $t h \leq t t \quad$ lawan $t h \geq t t$

Setelah diadakan perhitungan berdasarkan hasil statistik inferensial (eksperimen) jenis uji $\mathrm{t}$ diperoleh nilai t hitung: 5. Kriteria pengujiannya adalah:

$\mathrm{H}_{0}$ diterima jika $\mathrm{t}$ hitung $<\mathrm{t}$ tabel dan $\mathrm{H}_{0}$ ditolak jika $\mathrm{t}$ hitung $>\mathrm{t}$ tabel. Di mana t tabel $=$ d.b $-1=35-1=34$ (angka 34 dikategorikan d.b 30. d.b 30 inilah yang dilihat dalam tabel. Pada taraf signifikan $95 \%$ diperoleh t.s $0,95=1,70$.

Ternyata t hitung $(5)>t$ tabel $(1,70)$.

Berdasarkan perhitung di atas, maka $\mathrm{H}_{0}$ ditolak dan $\mathrm{H}_{1}$ (hipotesis penelitian) diterima.Dengan demikian, keefektifan metode experiential learning dalan pembelajaran keterampilan menulis deskriptif pada mahasiswa PGSD $\left(\mathrm{H}_{1}\right)$. Dengan diterimanya hipotesis yang diajukan, maka dapat dikatakan penggunaan metode exsperiential learning dalam menulis deskriptif mempunyai pengaruh signifikan terhadap peningkatan menulis deskriptif secara efektif pada mahasiswa PGSD.

Berdasarkan dari hasil analisis data tes kelas eksperimen diketahui bahwa nilai rata-rata hasil tes pada mahasiswa yang menggunakan metode eksperiential learning dalam pembelajaran keterampilan menulis deskriptif pada posttes (kelas eksperimen) adalah 7,5, sedangkan nilai rata-rata hasil pretest mahasiswa yang tidak menggunakan metode experiential learning dalam keterampilan menulis deksriptif adalah 6,. Jadi, Mahasiswa yang menggunakan metode experiential learning dalampembelajaran keterampilan menulis deskriptif mempunyai kemampuan secara efektif lebih tinggi sekitar 1,5 daripada tidak menggunakan metode experiential learning dalam pembelajaran keterampilan menulis deskriptifkepada mahasiswa.

Adapun tingkat keterampilan menulis deskriptif pada mahasiswa tanpa menggunakan metode experiential learning dikategorikan rendah dengan nilai rata-rata 6 , berada pada rentang $5,5-6,4$. Untuk lebih jelasnya dapat dilihat pada tabel 4 . berikut ini. 
Tabel 4. Klasifikasi Tingkat Keterampilan Menulis Deskriptif Mahasiswa (X)

\begin{tabular}{ccccc}
\hline No & Interval nilai & Tingkat hasil belajar & $\mathbf{X}_{\mathbf{1}}$ & $\mathbf{X}_{\mathbf{2}}$ \\
\hline 1. & $9,0-10$ & Sangat tinggi & & \\
2. & $8,0-8,9$ & Tinggi & & \\
3. & $6,5-7,9$ & Sedang & & \\
4. & $5,5-6,4$ & Rendah & 7,5 & \\
5. & $0,0-5,4$ & Sangat rendah & & 6 \\
\hline
\end{tabular}

Dilihat dari hasil analisis data perbandingan skor rata-rata hasil tes mahasiswa antara pretest dan posttes (kelas eksperimen) dengan menggunakan rumus uji t desai ketiga, dapat diketahui bahwa nilai t hitung yang diperoleh sebesar 5.Dalam penelitian ini peneliti telah mengungkap bahwa mahasiswa yang menggunakan metode experiential learning dalam menulis deskriptif mempunyai keterampilan menulis deskriptif secara efektif yang lebih tinggi daripada mahasiswa yang tidak menggunakan metode eksperiential learning, maka pengetesan yang digunakan adalah pengetesan satu arah. Dengan frekuensi (NU= d.b) sebesar 30, pada taraf signifikan $95 \%$ diperoleh $t . s_{0,95}=1,70$. Jadi t hitung lebih besar dari t tabel.

Oleh karena thitung lebih besar dari t tabel pada taraf signifikan 95\%, maka hipotesis nol $\left(\mathrm{H}_{0}\right)$ ditolak dan hipotesis alternatif $\left(\mathrm{H}_{1}\right)$ diterima. Hal ini berarti bahwa penggunaan metode experiential learning dapat meningkatkan keterampilan menulis deskriptif mahasiswa PGSD pokjar Barru. Hal ini memperkuat teori yang telah dikemukakan pada bagian latar belakang dan tinjauan pustaka, yaitu bahwa pembelajaran ketermpilan menulis deskriptifakan lebih efekif dengan menggunakan metode experiential learning.

\section{PENUTUP}

Hasil perhitungan perbandingan koefisien nilai rata-rata mahasiswa $(\mathrm{t}$ hitung) antara kelas eksperimen atau hasil posttes (X1) dan hasil pretest (X2) yang diperoleh sebesar 1,81 lebih besar dari t tabel pada taraf signifikan 95\%, yaitu $\alpha 0,95=1,70$. Oleh karena thitung lebih besar daripada t tabel pada taraf signifikan 95\%, maka hipotesis nol (HO) ditolak dan hipotesis alternatif (H1) diterima. Dengan demikian, penggunaan metode experiential learninglebih efektif untuk meningkatkan keterampilan menulis deskriptif mahasiswa PGSD pokjar Barru.

Sesuai hasil penelitian ini diajukan saran kepada dosen atau tutor agar lebih kreatif dan inovatif dalam meningkatkan pembelajaran tutorial, salah satu mateode yang dapat diaplikasikan adalah metode experiential learning dalam pembelajaran bahasa Indonesia khususnya dalam pembelajaran keterampilan menulis deskriptif. 
10 | Patmawati

\section{DAFTAR PUSTAKA}

Arikunto, Suharsimi. 1998. Prosedur Penelitian. Jakarta: Rineka Cipta.

Budiman, Eka. 1992. Menggebrak Dunia Mengarang. Jakarta: Pustaka Pembangunan Swadaya Closantara.

Depdikbud. 2005. Kamus Besar Bahasa Indonesia.Jakarta: Balai Pustaka.

Darmadi, kaswan. 1996. Meningkatkan Kemampuan Menulis. Yogyakarta: Andi Yogyakarta.

Djamarah, Syiful Bachri. 1996. Stategi Belajar Mengajar. Jakarta: Rineka Cipta. Hamalik, Oemar. 2007.Kurikulum dan Pembelajaran. Jakarta: Bumi Aksara.

Nurgiantoro, Burhan. 1995. Penilaian dalam Pengajaran Bahasa dan Sastra. Yogyakarta: BPF.

Rustan, E. (2016). Analisis Penggunaan Bahasa Indonesia Laras Hukum Pada Putusan Perkara Ekonomi Syariah Pengadilan Agama Makassar. Al Amwal, I(2), 166-176.

Rustan, E. (2017). Learning Creative Writing Model Based on Neurolinguistic Programming. International Journal of Language Education and Culture Review, 3(2), 13-29.

Sudjana, Nana. 2004. Penelitian dan Penilain Pendidikan. Bandung:Sinar Baru Algesindo.

Thaha, H., \& Rustan, E. (2017). Orientasi Religiusitas dan Efikasi Diri dalam Hubungannya dengan Kebermaknaan Pendidikan Agama Islam pada Mahasiswa IAIN Palopo. Studi Agama Dan Masyarakat, 13(2), 163-179. 